\title{
Differential expression of AP-1 transcription factors in human prostate LNCaP and PC-3 cells: role of Fra-1 in transition to CRPC status
}

\author{
K. Kavya ${ }^{1}$ M. Naveen Kumar ${ }^{1} \cdot$ Rajeshwari H. Patil $^{1} \cdot$ Shubha M. Hegde $^{1}$ • \\ K. M. Kiran Kumar ${ }^{1} \cdot$ Rashmi Nagesh $^{1} \cdot$ R. L. Babu ${ }^{2,3}$ - Govindarajan T. Ramesh ${ }^{3}$. \\ S. Chidananda Sharma ${ }^{1}$
}

Received: 31 December 2016 / Accepted: 15 March 2017

(C) Springer Science+Business Media New York 2017

\begin{abstract}
Androgen receptor (AR) signaling axis plays a vital role in the development of prostate and critical in the progression of prostate cancer. Androgen withdrawal initially regresses tumors but eventually develops into aggressive castration-resistant prostate cancer (CRPC). Activator Protein-1 (AP-1) transcription factors are most likely to be associated with malignant transformation in prostate cancer. Hence, to determine the implication of AR and AP-1 in promoting the transition of prostate cancer to the androgen-independent state, we used AR-positive LNCaP and AR-negative PC-3 cells as an in vitro model system. The effect of dihydrotestosterone or anti-androgen bicalutamide on the cell proliferation and viability was assessed by MTT assay. Expression studies on AR, marker genesPSA, TMPRSS2, and different AP-1 factors were analyzed by semi-quantitative RT-PCR and expressions of AR and Fra-1 proteins were analyzed by Western blotting. Dihydrotestosterone induced the cell proliferation in $\mathrm{LNCaP}$ with no effect on PC-3 cells. Bicalutamide decreased the viability of both LNCaP and PC-3 cells. Dihydrotestosterone induced the expression of AR, PSA, c-Jun, and Fra-1
\end{abstract}

S. Chidananda Sharma

sharma@bub.ernet.in

K. Kavya

kavyajanu88@gmail.com

1 Department of Microbiology and Biotechnology, Bangalore University, Jnana Bharathi, Bengaluru 560 056, Karnataka, India

2 Department of Bioinformatics and Biotechnology, Karnataka State Women's University, Jnanashakthi Campus, Vijayapura 586 108, Karnataka, India

3 Department of Biology and Center for Biotechnology and Biomedical Sciences, Norfolk State University, Norfolk, VA, USA in $\mathrm{LNCaP}$ cells, and it was c-Jun and c-Fos in case of PC-3 cells, while bicalutamide decreased their expression. In addition, constitutive activation and non-regulation of Fra-1 by bicalutamide in PC-3 cells suggested that Fra-1, probably a key component, involved in transition of aggressive androgen-independent PC-3 cells with poor prognosis.

Keywords Androgen receptor - Dihydrotestosterone · Bicalutamide $\cdot$ CRPC $\cdot$ RT-PCR $\cdot$ Western blot

\section{Introduction}

Prostate cancer ( $\mathrm{PCa}$ ) is the most pervasive malignancy diagnosed and remains the second leading cause of cancerrelated mortality affecting men in Western countries [1]. The central role of androgens in the regulation of growth, differentiation, and death responses in both normal and cancerous prostate tissue is well recognized [2-4]. The cellular effect of androgens is mediated via the androgen receptor (AR), a ligand-activated transcription factor and a member of the nuclear receptor superfamily. AR is composed of an N-terminal domain (NTD) which contains a major activation domain, AF-1, a DNA-binding domain (DBD), a hinge region, and a C-terminal ligand-binding domain (LBD) containing a weak activation domain, AF-2 [5]. Unliganded AR is sequestered in the cytoplasm by heat shock proteins. AR upon binding to a hormone (testosterone or dihydrotestosterone-DHT) dissociates the heat shock proteins and translocates them into nucleus. Androgen-AR complex functions as a transcription factor that binds as a homodimer to the androgen-response element (ARE) present in the regulatory elements of target genes promoting transcription. Hence, the androgen receptor acts as a key protein in prostate cancer progression. It is upregulated in 
all the stages of the disease by gene amplification or by other, non-genomic mechanism of action [6, 7]. Many studies have shown that the inhibition of AR activity could be an effective approach for prostate cancer treatment. Androgen deprivation therapy (ADT) using AR antagonist represents a first-line treatment strategy for advanced, recurrent, and even metastatic prostate cancer [8]. Bicalutamide (BIC), a non-steroidal anti-androgen molecule, finds use in the treatment of locally advanced and metastatic prostate cancer. The drug BIC became popular owing to its tolerable side effect profile, ease of administration with long half-life, and offers an attractive alternative to the steroidal anti-androgens. It functions as a receptor antagonist and prevents the binding of DHT $[9,10]$. Despite the success of ABT, most tumors eventually relapse and develop into castration-resistant prostate cancer (CRPC) due to the aberrant restoration of AR activity [11]. AR is involved in the transcriptional regulation of prostate-specific marker genes such as prostate-specific antigen (PSA) and transmembrane protease serine 2 (TMPRSS2), and their expression correlates with tumor size and progression to next stage in prostatic cancer [12]. Hence, understanding the changes in AR signaling in the evolution of androgen-independent prostate cancer will be a key to the development of more effective hormone therapy.

Activator protein-1 (AP-1) contributes to the development and progression of prostatic malignancies by regulating the expression of genes involved in proliferation, apoptosis, and angiogenesis, as well as in tumor invasion and metastasis [13, 14]. AP-1 transcription factors comprise a ubiquitously expressed family of proteins that include the Jun (e.g., c-Jun, Jun-B, Jun-D), Fos (e.g., c-Fos, Fos-B, Fra-1, Fra-2), ATF activating transcription factor (ATF2, LRFI/ATF3), and MAF musculoaponeurotic fibrosarcoma (c-Maf, MafB, MafA, MafG/F/K) proto-oncoproteins. The main AP-1 proteins in mammalian cells are Fos and Jun, which form hetero-(Jun-Fos or Jun-Fra) or homodimers (Jun-Jun) complex $[15,16]$. The number of combination of Jun (c-Jun, Jun-D, Jun-B) and Fos (c-Fos, Fos-B, Fra1, Fra-2) creates an enormous functional diversity with individual AP-1 proteins probably engaged in different cell functions [17]. They interact via a leucine-zipper domain and bind to AP-1 consensus sequence known as TPAresponsive elements (TREs) TGA(C/G) TCA or Cyclic AMP-responsive elements (CREs) TGACGTCA. This element is known to be present within the regulatory region of several genes including c-Jun [18]. The AP-1 complex acts as a "signal converter" [19], which mediates responses to cellular signals by binding to DNA and producing changes in gene transcription that ultimately lead to physiological changes of a cell.

The cellular changes regulated by androgen receptor due to androgen DHT and anti-androgen BIC exposure may result in change of the cellular reduction/oxidation (redox) state in human prostate cancer cells [20]. These may in turn affect the transcription factors that are sensitive to cellular redox status, such as the AP-1 transcription factors [21]. Additionally, both transrepressive and transactivating cross-talk may occur between the androgen receptor and AP-1 [22]. Different AP-1 factors' expression pattern is a stage- and tissue-specific, and may be fundamental to the process of oncogenesis. Interestingly, it has been suggested that Fos and Jun proteins were clearly elevated in androgen-independent tumors in a mouse model [23]. Studies from our laboratory suggested that c-Jun, c-Fos, and Fra-1 were elevated in breast cancer MCF-7 cells and that may be attributed to their actions on estrogen receptor [24]. Thus, regulating AP-1 activity with respect to AR may be an important event in prostate cancer development and progression.

Hence, in the present study, we investigated the role of androgen DHT and anti-androgen BIC on the expression patterns of AR, AR target genes, AP-1 factors, and their effect on cell cycle regulators and apoptotic genes using LNCaP and PC-3 cells. LNCaP cells are demonstrated to be androgen receptor positive with low tumorigenicity compared to androgen receptor negative and highly aggressive tumorigenic PC-3 cells. The study provides insights into the role of molecular pathways, in the development of aggressive form of prostate cancer, and may help in identification of a target for therapeutic intervention.

\section{Materials and methods}

\section{Materials}

Human prostate cancer $\mathrm{LNCaP}$ and $\mathrm{PC}-3$ cell lines were purchased from NCCS (Pune, India); dihydrotestosterone (DHT), bicalutamide (BIC), TRIzol, Oligo's forward and reverse primers for different AP-1 factors, AR, PSA, TMPRSS2, $\beta$-actin, cell cycle regulators, and apoptotic genes (Table 1) were designed and purchased from Sigma-Aldrich (St. Louis, USA). Fetal bovine serum (FBS), penicillin, streptomycin, glutamine, RPMI 1640 medium, 3-(4,5-dimethylthiazol-2-yl)-2,5 diphenyltetrazolium bromide (MTT), dimethyl sulfoxide (DMSO), trypan blue, agarose, and Ethidium bromide were purchased from Himedia (Mumbai, India). OligodTs and superscript reverse transcriptase were obtained from Invitrogen BioServices India Pvt. Ltd (Bangalore, India); Antibodies of GAPDH, AR, and Fra-1 were purchased from NeoBiolab (MA, USA), and anti-rabbit antibody-HRP conjugate was 
Table 1 Sequence of primers used in RT-PCR studies

\begin{tabular}{|c|c|c|c|c|}
\hline Gene & Primer sequence $\left(5^{\prime} \rightarrow 3^{\prime}\right)$ & $\begin{array}{l}\text { Annealing } \\
\text { temp. }\left({ }^{\circ} \mathrm{C}\right)\end{array}$ & $\begin{array}{l}\text { Product } \\
\text { size (bp) }\end{array}$ & Reference \\
\hline \multicolumn{5}{|c|}{ Hormonal receptor } \\
\hline $\mathrm{AR}$ & $\begin{array}{l}\text { F: CGACTACCGCATCATCACAG } \\
\text { R: TCTGGAAAGCTCCTCGGTAG }\end{array}$ & 59 & 169 & Present study \\
\hline \multicolumn{5}{|c|}{ AR marker genes } \\
\hline PSA & $\begin{array}{l}\text { F: AGGTCAGCCACAGCTTCCCA } \\
\text { R: GGGCAGGTCCATGACCTTCA }\end{array}$ & 58 & 155 & Present study \\
\hline TMPRSS2 & $\begin{array}{l}\text { F: AGGTGCATCCGGCTCAGTA } \\
\text { R:GGGTCAAGGTGATGCACAGT }\end{array}$ & 62 & 159 & Present study \\
\hline \multicolumn{5}{|l|}{ AP-1 factors } \\
\hline c-Jun & $\begin{array}{l}\text { F: GCCTACAGATGAACTCTTTCTGGC } \\
\text { R: CCTGAAACATCGCACTATCCTTTG }\end{array}$ & 64 & 525 & {$[27]$} \\
\hline Jun-D & $\begin{array}{l}\text { F: CGCAGCCTCAAACCCTGCCTTTCC } \\
\text { R: AAACAGGAATGTGGACTCGTAG }\end{array}$ & 64 & 500 & {$[27]$} \\
\hline Jun-B & $\begin{array}{l}\text { F: CCAGTCCTTCCACCTCGACGTTTACAAG } \\
\text { R: GACTAAGTGCGTGTTTCTTTTCCACAGTAC }\end{array}$ & 58 & 257 & {$[27]$} \\
\hline c-Fos & $\begin{array}{l}\text { F: TCTTCCTTCGTCTTCACC } \\
\text { R: AATCAGAACACACTATTGCC }\end{array}$ & 58 & 577 & {$[27]$} \\
\hline Fra-1 & $\begin{array}{l}\text { F: AGGAAGGAACTGACCGAC } \\
\text { R: GAAGGGGAGGAGACATTG }\end{array}$ & 60 & 497 & {$[27]$} \\
\hline Fra-2 & $\begin{array}{l}\text { F: AGGAGGAGAGATGAGCAG } \\
\text { R: GGATAGGTGAAGACGAGG }\end{array}$ & 60 & 518 & {$[27]$} \\
\hline Fos-B & $\begin{array}{l}\text { F: TGTCCCAGGGAAATGTTTCAGGC } \\
\text { R: ACTGGTAGTTCCGCTGGTGGAAGG }\end{array}$ & 56 & 451 & Present study \\
\hline \multicolumn{5}{|c|}{ Cell cycle regulators } \\
\hline P53 & $\begin{array}{l}\text { F: GAGCCCCCTCTGAGTCAG } \\
\text { R: GCAAAAACATCTTGTTGAG }\end{array}$ & 56 & 375 & {$[27]$} \\
\hline P21 & $\begin{array}{l}\text { F: GATCACAAGCAGTGGGGTGA } \\
\text { R:CTGAGTGACTGCACGACCTT }\end{array}$ & 58 & 160 & Present study \\
\hline CDK4 & $\begin{array}{l}\text { F: AGTGGCGGATCCATGGCTACCTCTCGATAT } \\
\text { R: TCTCGGAAGCTTTCACTCCGGATTACCTTCA }\end{array}$ & 60 & 912 & [27] \\
\hline Cyclin D1 & $\begin{array}{l}\text { F: AGACCTGCGCGCCCTCGGTG } \\
\text { R: GTAGTAGGACAGGAAGTTGTTG }\end{array}$ & 58 & 574 & {$[27]$} \\
\hline Cyclin E1 & $\begin{array}{l}\text { F: GTCCTGGCTGAATGTATACATGC } \\
\text { R: CCCTATTTTGTTCAGACAACAT }\end{array}$ & 60 & 415 & {$[27]$} \\
\hline \multicolumn{5}{|c|}{ Apoptotic genes } \\
\hline $\mathrm{Bcl}-2$ & $\begin{array}{l}\text { F: AGATGTCCAGCCAGCTGCACCTGAC } \\
\text { R: AGATAGGCACCCAGGGTGATGCAAGCT }\end{array}$ & 62 & 365 & {$[27]$} \\
\hline Bax & $\begin{array}{l}\text { F: AAGCTGAGCGAGTGTCTCAAGCGC } \\
\text { R: TCCCGCCACAAAGATGGTCACG }\end{array}$ & 61 & 366 & {$[27]$} \\
\hline Caspase- 8 & $\begin{array}{l}\text { F: GATATTGGGGAACAACTGGAC } \\
\text { R: CATGTCATCATCCAGTTTGCA }\end{array}$ & 58 & 366 & Present study \\
\hline Caspase-3 & $\begin{array}{l}\text { F: TTAATAAAGGTATCCATGGAGAACACT } \\
\text { R: TTAGTGATAAAAATAGAGTTCTTTTGTGAG }\end{array}$ & 59 & 848 & Present study \\
\hline$\beta$-actin & $\begin{array}{l}\text { F: TACCACTGGCATCGTGATGGACT } \\
\text { R: TCCTTCTGCATCCTGTCGGCAAT }\end{array}$ & 62 & 516 & {$[27]$} \\
\hline
\end{tabular}

Columns 3 and 4 show annealing temperatures and the size of the amplified products

$F$ forward, $R$ reverse purchased from Imgenex India Pvt. Ltd. (Bhubaneswar, India). Taq DNA polymerase $(1 \mathrm{U} / \mu \mathrm{l})$ and Luminata Forte Western HRP substrate were procured from Merck-Millipore (Mumbai, India).

\section{Culturing of cells}

LNCaP and PC-3 Cells were grown in $25 \mathrm{~cm}^{2}$ culture flasks using RPMI 1640 media with 10\% FBS, $100 \mathrm{U} / \mathrm{ml}$ penicillin, $100 \mathrm{mg} / \mathrm{ml}$ streptomycin, and $2 \mathrm{mM}$ L-glutamine. 
The cells were cultured in an incubator under humidified atmosphere at $37^{\circ} \mathrm{C}$ by passing $5 \% \mathrm{CO} 2$. Flask containing 90-100\% confluent cells were sub-cultured in 96-well plate $\left(3 \times 10^{3}\right.$ cells/well $)$ and in a 6 -well plate $\left(5 \times 10^{5}\right.$ cells/ well), for the treatment and expression studies.

\section{MTT assay}

Analysis of cell viability was carried out using MTT assay as per the protocol described earlier [25]. MTT is a pale yellow substrate taken up by live cells and reduced in mitochondria by Succinate dehydrogenase to yield a dark blue formazan product. LNCaP or PC-3 cells $\left(3 \times 10^{3}\right.$ cells/ well) in RPMI-1640 medium in a volume of $200 \mu \mathrm{l}$ were seeded into a 96-well culture plate and incubated overnight at $37^{\circ} \mathrm{C}$ with the supply of $5 \% \mathrm{CO} 2$. Cells were treated with or without different concentrations of DHT or BIC and incubated further for $48 \mathrm{~h}$. The cells were washed with PBS, and treated with $20 \mu \mathrm{l}$ of MTT (5 mg/ $\mathrm{ml}$ ) and incubated for $4 \mathrm{~h}$ at $37^{\circ} \mathrm{C}$ in a $\mathrm{CO} 2$ incubator. The blue formazan products formed in cells were dissolved in DMSO $(100 \mu \mathrm{l})$ and spectrophotometrically measured at $540 \mathrm{~nm}$. The effect of DHT or BIC on cell viability was calculated and represented graphically as $\%$ of viable cells compared to control.

\section{RNA isolation and semi-quantitative RT-PCR analysis}

Overnight cultures of $\mathrm{LNCaP}$ or PC- 3 cells $\left(5 \times 10^{5}\right.$ cells/ well) in a six-well plate were incubated with or without DHT $(10 \mathrm{nM})$ or BIC $(50$ or $75 \mu \mathrm{M})$ for $48 \mathrm{~h}$. Total RNA was isolated from control, and treated cells using TRIzol reagent as per the protocol standardized in the laboratory and instructions provided by the manufacturer. Reverse transcription of RNA and PCR analysis were carried out as per the protocol described earlier [26]. Total RNA ( $2 \mu \mathrm{g})$ of different samples was reverse-transcribed using Oligo (dT) primers and superscript reverse transcriptase. The complementary DNA (cDNA) was subjected to 30 cycles of PCR in a gradient Eppendorf thermo cycler using different forward and reverse primers of genes of AR, PSA, TMPRSS2, AP-1 factors, cell cycle regulators, and apoptotic regulators (Table 1) as described earlier [27]. The $\beta$-actin was used as a positive control and for normalization. First-strand cDNA $(1 \mu \mathrm{l})$ was mixed with $2 \mu \mathrm{l}$ of $10 \mathrm{x}$ PCR buffer $(200 \mathrm{mM}$ Tris- $\mathrm{HCl} \mathrm{pH} \mathrm{8.4,} 500 \mathrm{mM} \mathrm{KCl}), 1 \mu \mathrm{l}$ of $50 \mathrm{mMMgCl} 2$, $1 \mu \mathrm{l}$ each of $10 \mathrm{pmol}$ of forward and reverse primers, $1 \mu \mathrm{l}$ of $10 \mathrm{mM}$ dNTP's, and one unit of Taq DNA polymerase in a volume of $20 \mu \mathrm{l}$ reaction mixture. PCR amplification conditions used were initial denaturation at $94^{\circ} \mathrm{C}$ for $5 \mathrm{~min}$ followed by 30 cycles with $94^{\circ} \mathrm{C}$ for $1 \mathrm{~min}$, specific annealing temperatures (Table 1) for $1 \mathrm{~min}$, elongation at $72{ }^{\circ} \mathrm{C}$ for $50 \mathrm{~s}$, and a final extension cycle at $72^{\circ} \mathrm{C}$ for $7 \mathrm{~min}$.
Amplified PCR products were analyzed by electrophoresis using $1 \%$ agarose gels and $1 \times$ TAE electrode buffer.

\section{Western blot analysis of AR and Fra-1}

LNCaP or PC- 3 cells $\left(5 \times 10^{5}\right.$ cells/well $)$ in a six-well plate were incubated with or without DHT $(10 \mathrm{nM})$ or BIC (50 or $75 \mu \mathrm{M}$ ) for $48 \mathrm{~h}$ and subjected to western blot analysis as described earlier [27] with minor modifications. Cells were lysed in $0.2 \mathrm{ml}$ of cold lysis buffer [Tris- $\mathrm{HCl}(50 \mathrm{mM}) \mathrm{pH}$ 8.0, NaCl (150 mM), NP-40 (1.0\%), and PMSF $(100 \mu \mathrm{M})]$. Protein concentrations of cell lysates were measured by Bradford's method [28]. Equal amounts of protein $(40 \mu \mathrm{g} /$ lane) were electrophoresed on 4-12\% sodium dodecyl sulfate-polyacrylamide gel and transferred onto PVDF membrane. Membrane was blocked with 5\% Carnation fat-free milk for $1 \mathrm{~h}$ at room temperature. Blots were incubated with primary antibody (anti AR and Fra-1) in blocking solution (1:500) for $1 \mathrm{~h}$, washed and incubated with anti-rabbit antibody-HRP (1:1000), and further incubated for $1 \mathrm{~h}$ at room temperature. Proteins were visualized using Luminata Forte Western HRP substrate and as per the specifications provided by the supplier in a Syngene Gel Documentation system (MD, USA). GAPDH was used as an internal control for normalization. Immunoreactive bands were quantified using image analysis software (Image J).

\section{Statistical analysis}

The experimental data are shown as mean \pm SD from at least three independent experiments. Statistical analysis was done by Student's $t$ test and one-way ANOVA, followed by post hoc Tukey test, and values were considered as statistically significant if $* P<0.05, * * P<0.005$ compared to control, and if ${ }^{\#} P<0.05$ compared to DHT-treated sample.

\section{Results}

\section{Dihydrotestosterone (DHT) induces proliferation of $\mathrm{LNCaP}$ cells}

To study the effect of DHT on cell growth, the LNCaP cells or PC-3 cells were treated with or without different concentrations of DHT (1-100 nM) for $48 \mathrm{~h}$, and cell viability was determined by MTT assay. The results show that only in androgen-positive LNCaP cells, the cell number increases with increased concentration of DHT in a dose-dependent manner. The significant increase in cell number (18\%) was observed at $25 \mathrm{nM}$ concentration of DHT $(P>0.05)$ and the cell number remained almost same at higher concentrations of DHT (25 and $100 \mathrm{nM})$ 
(a)

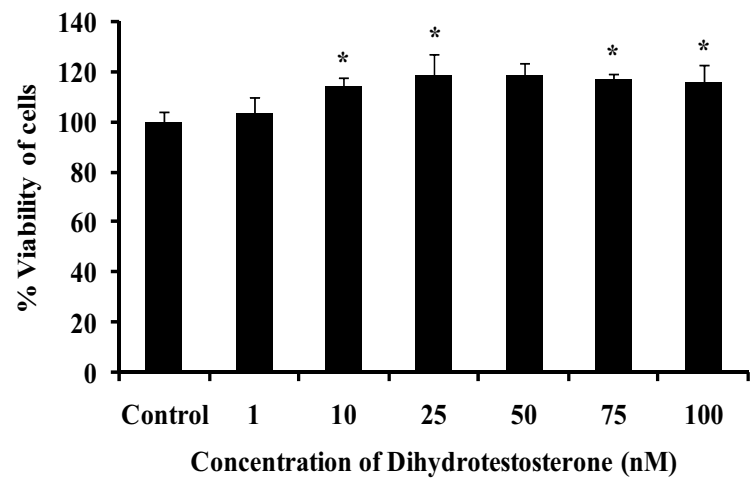

Fig. 1 Effect of DHT on the proliferation of (a) LNCaP cells and (b) PC-3 cells. LNCaP or PC-3 cells were treated with or without different concentrations of DHT (1-100 nM) in a 96-well plate for $48 \mathrm{~h}$, and the growth of the cells was analyzed by MTT assay. Results were expressed as \% viability of cells compared to control (mean $\pm \mathrm{SD}$,

(Fig. 1a). Similar results were obtained by counting the viable cells using trypan blue dye exclusion method (data not shown) in a Neubauer counting chamber. However, in androgen-negative PC-3 cells, the DHT at all concentrations found to have little or no effect in cell number (Fig. 1b). The results confirm that LNCaP cells are androgen-responsive, while PC-3 cells were androgennon-responsive cells.

\section{Bicalutamide (BIC), an anti-androgen, reduces the viability of both $\mathrm{LNCaP}$ and $\mathrm{PC}-3$ cells}

To study cytotoxic effect of anti-androgen BIC on cells, the LNCaP or PC-3 cells were treated with or without different

(a)

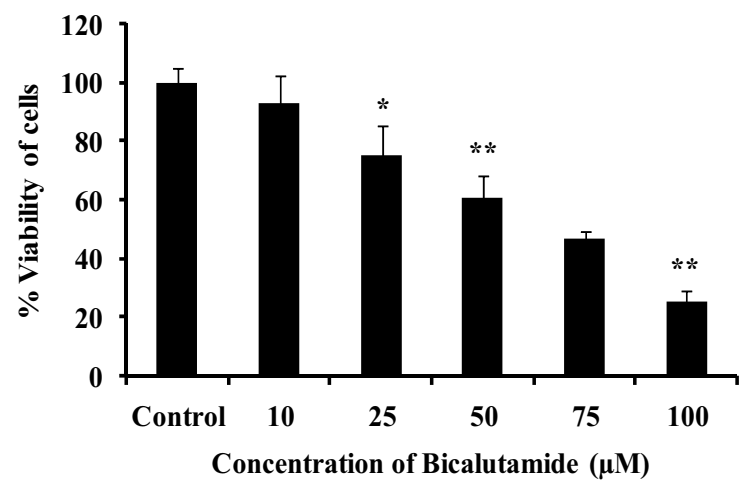

Fig. 2 Effect of BIC on the viability of (a) LNCaP cells and (b) PC-3 cells. LNCaP or PC-3 cells were treated with or without different concentrations of BIC $(10-100 \mu \mathrm{M})$ in a 96-well plate for $48 \mathrm{~h}$, and the cell viability was determined by MTT assay. Results were expressed as \% viability of cells compared to control (mean $\pm \mathrm{SD}$, (b)

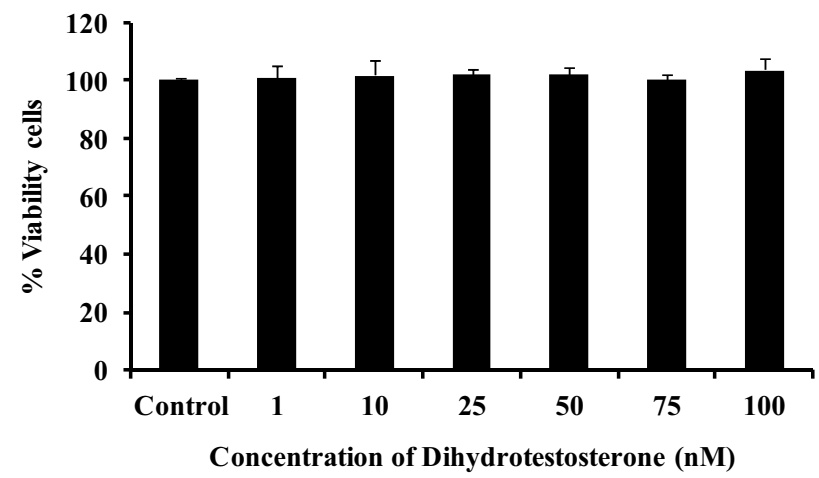

$\mathrm{n}=8$ ). Values are significantly different from control if $* P<0.05$, ** $P<0.005$ by student $t$ test, one-way anova, and post hoc Tukey test. The results are shown as a representative of three independent experiments

concentrations of BIC (10-100 $\mu \mathrm{M})$ for $48 \mathrm{~h}$, and cell viability was determined by MTT assay. Results show that BIC decreases the cell viability of both LNCaP and PC-3 cells in a dose-dependent manner. The statistically significant decrease of 25 and $17 \%$ was observed at 25 and $50 \mu \mathrm{M}$ concentration of BIC in LNCaP and PC-3 cells, respectively. (Fig. 2a, b). The similar results and dose-dependent response of decrease in both $\mathrm{LNCaP}$ and PC-3 cells were observed by counting viable cells using dye exclusion method (data not shown). Note that the inhibitory effect of $\mathrm{BIC}$ was more effective in $\mathrm{LNCaP}$ as the $\mathrm{IC}_{50}$ of $\mathrm{BIC}$ was found to be $68 \mu \mathrm{M}$ compared to $100 \mu \mathrm{M}$ in PC-3 cells. However, the BIC significantly decreases cell viability in both LNCaP and PC-3 cells.

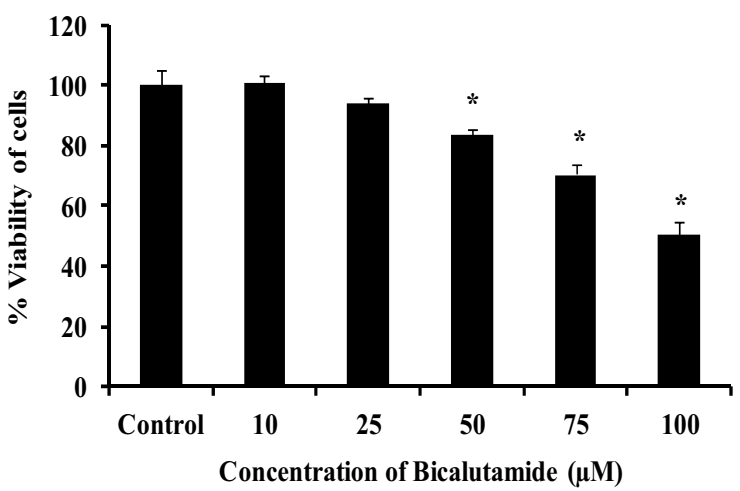

$\mathrm{n}=8$ ). Values are significantly different from control if $* P<0.05$, $* * P<0.005$ by student $t$ test, followed by one-way anova and post hoc Tukey test. The results are shown as a representative of three independent experiments 


\section{DHT induces but $\mathrm{BIC}$ reduces the mRNA expression of $A R$ in $L N C a P$ cells}

To assess the effect of DHT and BIC on the expression of them RNAs of AR in LNCaP or PC-3 cells, the cells were treated with or without DHT or BIC and RNA levels were analyzed by semi-quantitative RT-PCR. Results show that the LNCaP cells treated with DHT $(10 \mathrm{nM})$ induced the AR mRNA expression by more than 1.75 -fold compared to control, while cells treated with BIC $(50 \mu \mathrm{M})$ decreased the mRNA expression of AR by more than $52 \%$ compared to control (Fig. 3a). However, PC-3 cells show very negligible amount of AR mRNA transcripts both in control as well as in DHT- or BIC-treated samples (Fig. 3b). Results suggested that LNCaP cells are androgen-responsive and ARpositive cells, while PC-3 cells are androgen-non-responsive and AR-negative cells.

\section{BIC significantly inhibits the expression} of androgen-regulated genes (PSA and TMPRSS2) in $\mathrm{LNCaP}$ cells

To analyze the effect of DHT and BIC on the expression of AR-regulated marker genes(prostate-specific antigen (PSA) and transmembrane protease serine 2 (TMPRSS2)), the LNCaP and PC-3 cells were treated

(a)
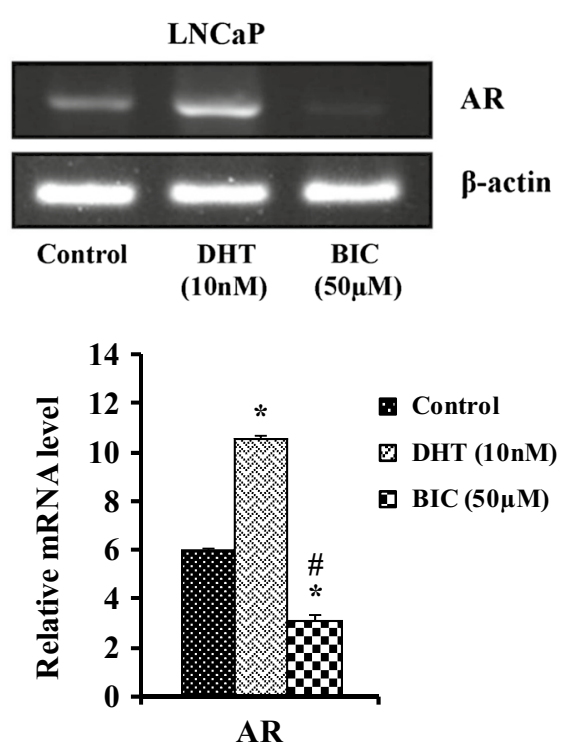

Fig. 3 Effect of DHT and BIC on the mRNA levels of AR in (a) LNCaP cells and (b) PC-3 cells. LNCaP or PC- 3 cells $\left(5 \times 10^{5}\right.$ cells/ well) were treated with or without DHT $(10 \mathrm{nM})$ or BIC (50 or $75 \mu \mathrm{M}$ ) for $48 \mathrm{~h}$. The cDNA was prepared from total RNA and subjected to 30 cycles of PCR using specific primers of AR. Expression of $\beta$-actin was used as a positive control and for normalization. The with DHT and BIC, and the mRNA levels of PSA and TMPRSS2 were analyzed by semi-quantitative RT-PCR. Results show that the AR-positive LNCaP cells treated with DHT induced mRNA expression of PSA by more than 0.8 -fold, and no significant induction was seen with TMPRSS2m RNAs, While BIC significantly decreased the expression of mRNAs of both PSA and TMPRSS2 by 54 and $76 \%$, respectively, compared to control (Fig. 4a). However, in AR-negative PC-3 cells, DHT marginally induced mRNAs of both PSA and TMPRSS 2 and BIC decreased marginally the expression of mRNAs of PSA and TMPRSS2 genes (Fig. 4b).The differential expression of AR-regulated genes with the treatment in $\mathrm{LNCaP}$ and PC- 3 cells may be due to difference in their AR status.

\section{Differential expression of mRNAs of AP-1 factors in $\mathrm{LNCaP}$ and $\mathrm{PC}-3$ cells}

To analyze the effect of androgen and anti-androgen on the expression of mRNA levels of different AP-1 factors in LNCaP and PC- 3 cells, the cells were treated with or without DHT(10 nM) or BIC (50 and $75 \mu \mathrm{M})$ for $48 \mathrm{~h}$ and the total RNA was subjected to RT-PCR. The results show that the Jun (c-Jun, Jun-B, and Jun-D) and Fos (c-Fos, Fra-1, Fra-2, and Fos-B) family member mRNA transcripts were expressed at different levels in both LNCaP and PC-3 cells.

(b)
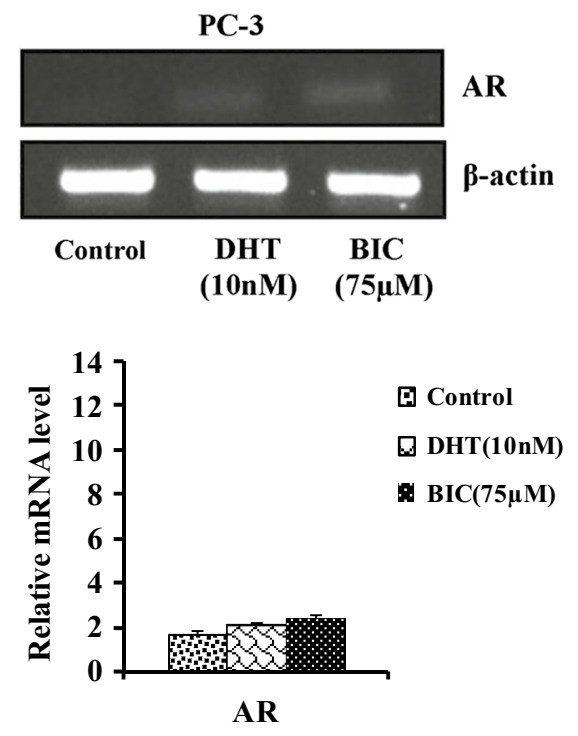

mRNA levels of AR were analyzed on $1 \%$ agarose gel. Data represent mean \pm SD from three independent experiments. $* P<0.05$ compared to control cells and ${ }^{\#} P<0.05$ in compared to DHT-treated condition values using one-way ANOVA followed by post hoc Tukey test. The bar graph represents the densitometric analysis of mRNA levels of AR 
(a)
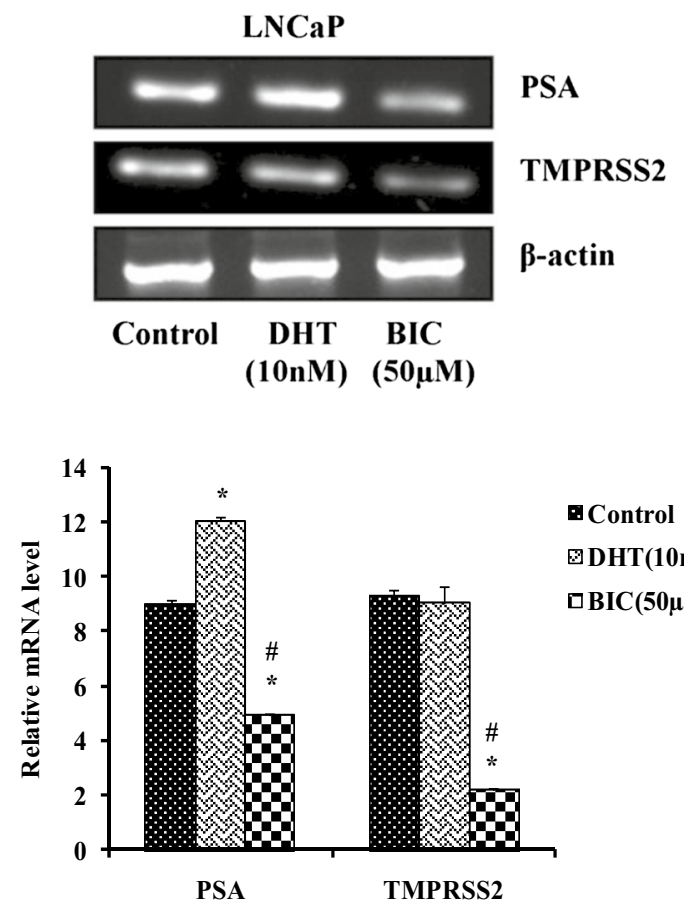

Fig. 4 Effect of DHT and BIC on the mRNA levels of PSA and TMPRSS2 in (a) LNCaP cells and (b) PC-3 cells. LNCaP or PC-3 cells $\left(5 \times 10^{5}\right.$ cells/well $)$ were treated with or without DHT $(10 \mathrm{nM})$ or BIC $(50$ or $75 \mu \mathrm{M})$ for $48 \mathrm{~h}$. The cDNA was prepared from total RNA and subjected to 30 cycles of PCR using specific primers of PSA and TMPRSS2. Expression of $\beta$-actin was used as a positive control and for normalization. The mRNA levels of PSA and TMPRSS2

In LNCaP cells, DHT induced c-Jun and Fra-1 mRNAs significantly by 1.5 - and 1.75 -fold, respectively, and decreased the expression of Fra- 2 by $31 \%$ compared to control (Fig. 5a). However, BIC significantly decreased the mRNA transcripts of c-Jun by $25 \%$, Fra- 1 by $48 \%$, and Fos-B by $51 \%$, and increased the gene expression of Jun-D by $1.9-$ fold compared to control (Fig. 5a). In PC-3 cells, DHT significantly induced the expression of c-Jun by onefold and c-Fos by 1.7 -fold and also marginally decreased the expression of Fra- 2 and Fos-B mRNA transcripts by 18 and $16 \%$, respectively, compared to control (Fig. $5 \mathrm{~b}$ ). The treatment with BIC significantly decreased the gene expression of c-Jun by $25 \%$ and c-Fos by $51 \%$ and also increased the expression of Fra-2 and Fos-B mRNA transcripts by 0.9and 0.8-fold, respectively, compared to control. However, both DHT and BIC show no effect on the expression of Jun-D and Fra-1 mRNAs (Fig. 5b). The results suggested that there is a difference in the expression of individual AP-1 factors between LNCaP and PC-3 cells, and therefore the expression of individual AP-1 factors is probably stagespecific, playing a major role in the development of CRPC. (b)
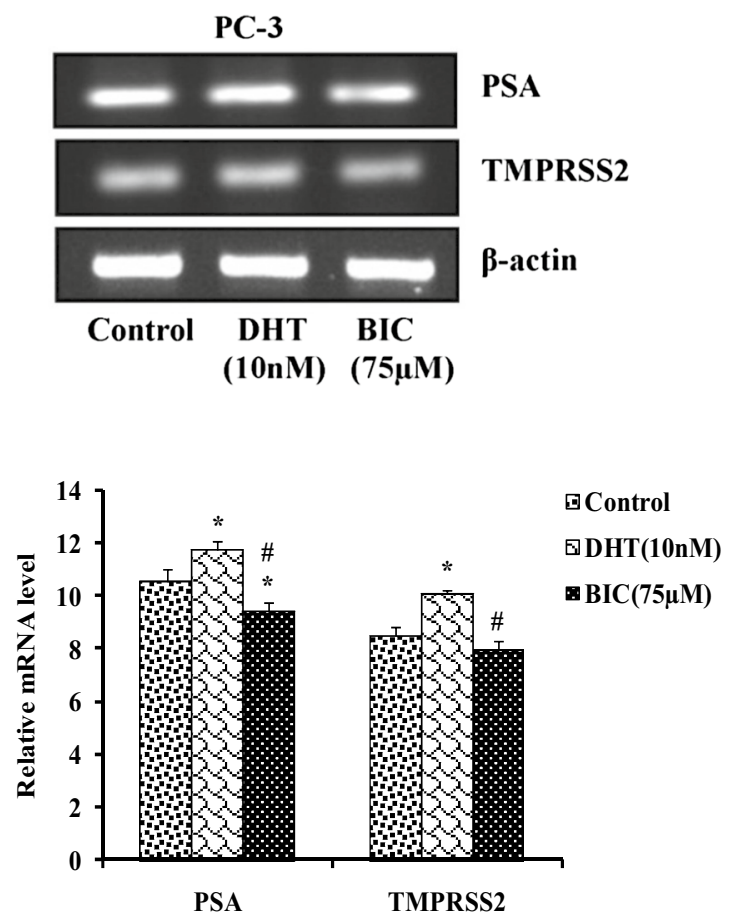

were analyzed on $1 \%$ agarose gel. Data represent mean \pm SD from three independent experiments. $* P<0.05$ compared to control cells and ${ }^{\#} P<0.05$ in compared to DHT-treated condition values using one-way ANOVA followed by post hoc Tukey test. The bar graph represents the densitometric analysis of mRNA levels of PSA and TMPRSS2

DHT induces but BIC inhibits the expression of AR and Fra-1 proteins in LNCaP cells, and constitutive increased expression of Fra-1 protein in PC-3 cells

LNCaP cells treated with DHT show significant increase in AR and Fra-1 protein level by more than 26 and $65 \%$, respectively, compared to control. BIC significantly decreased both control and DHT induced AR by 65 and 75\%, while Fra-1 by 40 and 55\%, respectively (Fig. 6a). PC-3 cells exhibited negligible or null expression of AR and higher constitutive expression of Fra-1 proteins both in control as well as DHT- and BIC-treated samples (Fig. 6b).

\section{DHT inhibits and BIC activates the co-repressor cyclin D1 in LNCaP cells, while BIC inhibits cyclin E1 in both $\mathrm{LNCaP}$ and PC-3 cells}

To study the effects of DHT and BIC on the expression of mRNAs levels of different cell cycle regulators in $\mathrm{LNCaP}$ and PC-3 cells, cells were treated with or without DHT (10 $\mathrm{nM})$ or BIC $(50$ and $70 \mu \mathrm{M})$ for $48 \mathrm{~h}$. LNCaP cells treated with DHT induced cyclin E1 mRNA significantly by 
(a)
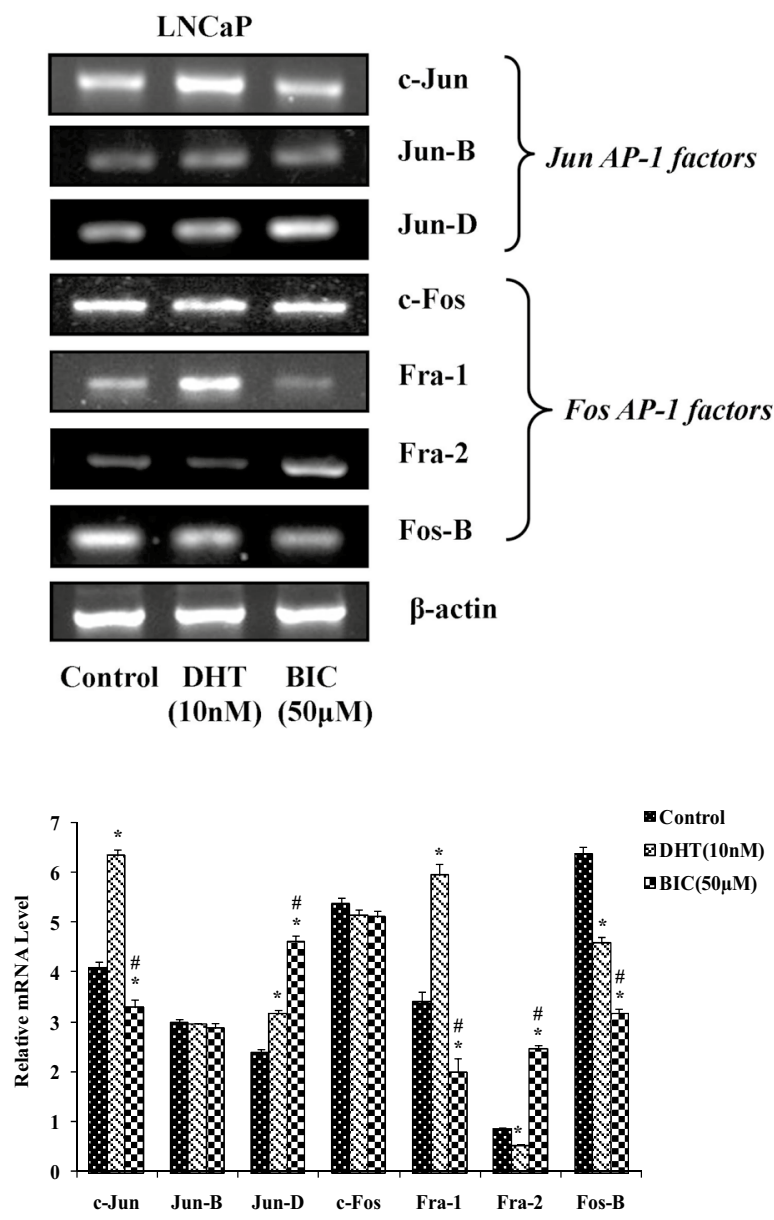

Fig. 5 Expression pattern of mRNAs of AP-1 factors (Jun and Fos family) in (a) LNCaP cells and (b) PC-3 cells. LNCaP or PC-3 cells $\left(5 \times 10^{5}\right.$ cells/well $)$ treated with or without DHT $(10 \mathrm{nM})$ or BIC $(50$ and $75 \mu \mathrm{M}$ ) for $48 \mathrm{~h}$ in 6-well plate. Total RNA was isolated from control and treated cells. cDNA was prepared by RT and subjected to 30 cycles of PCR using specific primers of Jun and Fos family members. Expression of $\beta$-actin was used as a positive control and

1.7-fold and decreased the expression of cyclin D1 by $51 \%$ compared to control, while the expressions of p53, p21, and CDK4 transcripts were unaffected (Fig. 7a). However, BIC treatment increased the cyclin D1 mRNA levels by 1.5fold, marginally increased the CDK4 transcript, and significantly decreased the levels of cyclin E1 and p 21 by 45 and $22 \%$, respectively. In PC-3 cells, while DHT significantly decreased the expression of p 21 by $26 \%$ and marginally decreased p53 transcripts by $10 \%$, BIC induced p 53 mRNA marginally by $10 \%$ and p 21 mRNA by $9 \%$ and significantly decreased $(70 \%)$ cyclin E1 mRNA transcripts (Fig. 7b). Results suggested that BIC has a prominent effect on the expression of cyclin D1 in LNCaP than PC-3 cells. (b)
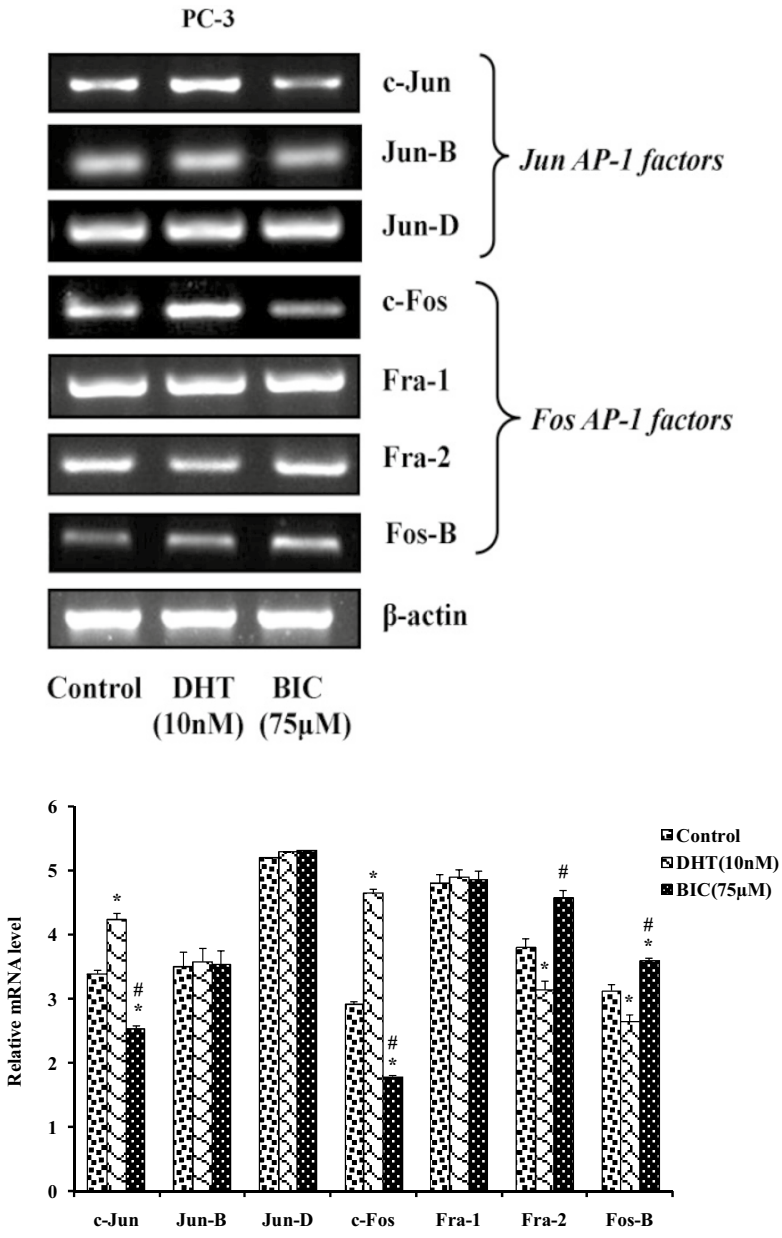

for normalization. Data shown are means \pm SD from three independent experiments. Differences in AP-1 factors of mRNA levels are statistically significant: if $* P<0.05$ compared to control cells, ${ }^{\#} P<0.05$ compared with DHT-treated condition values using one-way ANOVA followed by post hoc Tukey test. The bar graph represents the densitometric analysis of mRNA levels of AP-1 factors

\section{BIC induces apoptotic genes in $\mathrm{LNCaP}$ and $\mathrm{PC}-3$ cells}

LNCaP cells treated with $\mathrm{BIC}$ induced the expression of mRNAs pro-apoptotic gene Bax by 1.5 -fold and the initiator Caspase- 8 by 0.8 -fold. BIC also decreased the expression of anti-apoptotic $\mathrm{Bcl} 2$ by $38 \%$ in $\mathrm{LNCaP}$ cells (Fig. 8a). However, in PC-3 cells, BIC increased the expression of mRNAs of Bax, Caspase- 8 , and Caspase- 3 by 1-, 0.7-, and 0.8-fold, respectively, and significant decrease was observed with $\mathrm{Bcl} 2$ by $45 \%$, compared to control (Fig. 8b). DHT induced the expression of anti-apoptotic Bcl 2 marginally by 10 and $18 \%$, and had no effect on Bax, Caspase-8, and Caspase-3 in LNCaP and PC-3 cells. Result suggested that BIC induced apoptotic genes in both $\mathrm{LNCaP}$ and PC-3 cells. 
(a)
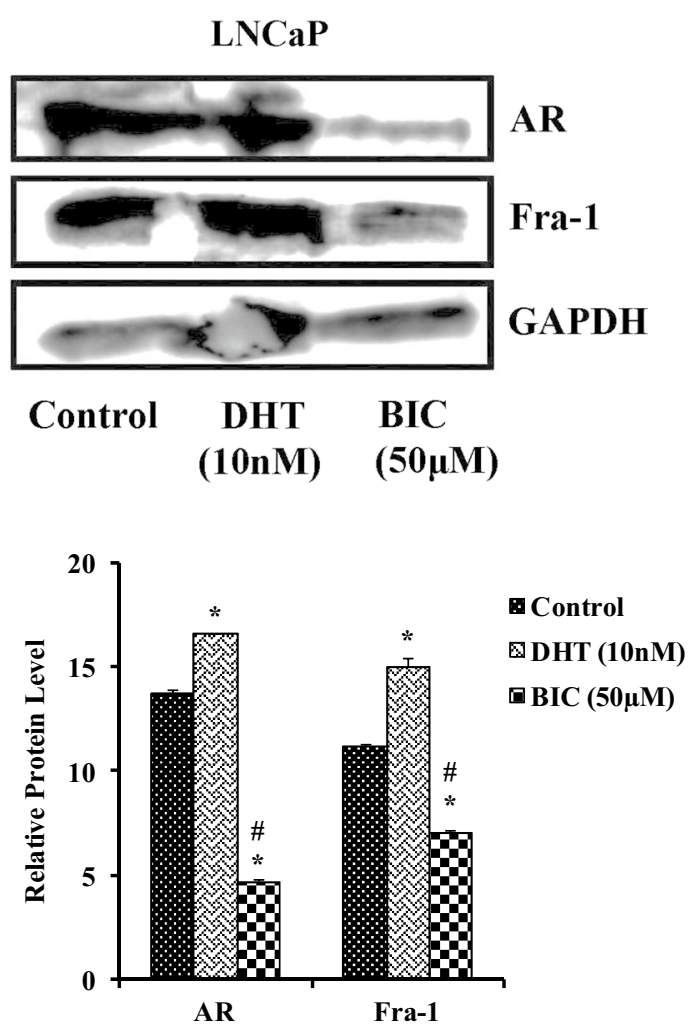

Fig. 6 Effect of DHT and BIC on the expression of AR and Fra-1 protein levels in (a) $\mathrm{LNCaP}$ cells and (b) PC-3 cells. LNCaP or PC-3 cells were treated with or without DHT $(10 \mathrm{nM})$ or BIC (50 or $75 \mu \mathrm{M}$ ) for $48 \mathrm{~h}$. Cell lysates were prepared using lysis buffer and equal amounts of protein $(40 \mu \mathrm{g})$ of cell lysates were analyzed by SDS-PAGE, transferred to PVDF membrane, and western blotting was carried out using AR, Fra-1, and GAPDH antibodies. The

\section{Discussion}

The progression of prostate cancer has been found to be androgen-dependent with androgen playing a key role in the proliferation, differentiation, and survival of prostate cancer cells $[29,30]$. The effect of androgens is mediated through the androgen receptor (AR), a ligand-modulated transcription factor belonging to a nuclear receptor superfamily that regulates its targeted gene expression [31, 32]. Early studies documented well that AR played complicated yet vital roles in the progression of PCa. Importantly, AR could either stimulate or suppress $\mathrm{PCa}$ progression via modulating cell proliferation or cell death with distinct mechanisms [33-35]. As a therapeutic modality for PCa, androgen deprivation therapy (ADT), which suppresses or interferes with the activity of the AR especially through the use of anti-androgens, is a well-known treatment strategy for prostate cancer [8]. Despite an initial favorable response, almost all patients invariably progress to a more (b)
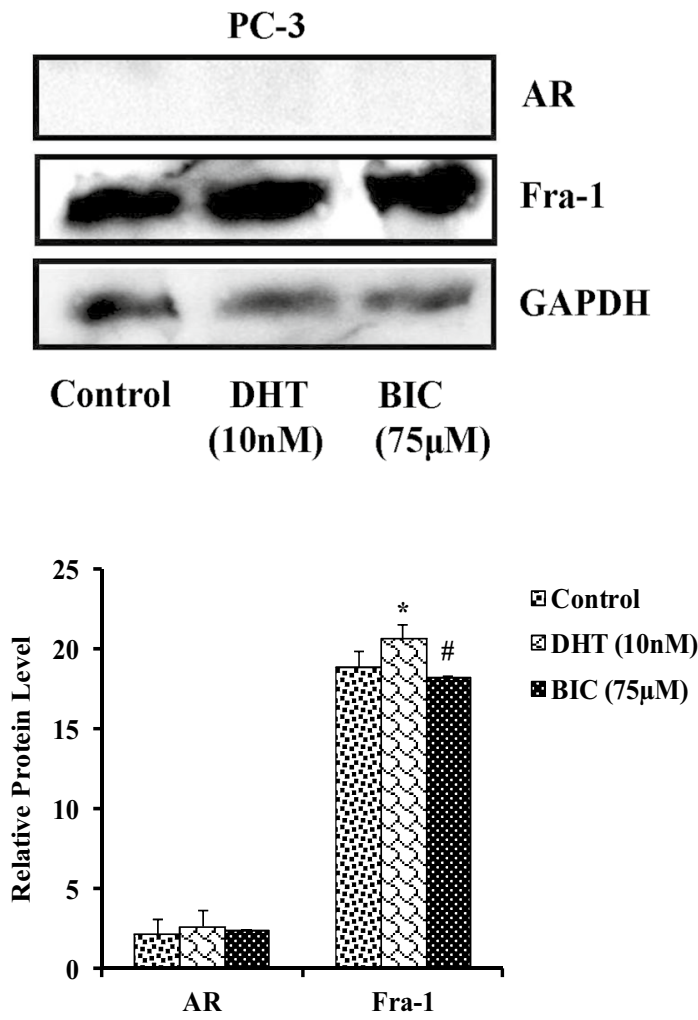

expressed protein level of GAPDH was used as control. Data represent mean \pm SD from three independent experiments. Differences in protein levels are statistically significant: if $* P<0.05$ compared to control cells and ${ }^{\#} P<0.05$ in compared to DHT-treated condition values using one-way ANOVA followed by post hoc Tukey test. The bar graph represents the densitometric analysis of protein levels

aggressive, castrate-resistant phenotype. Considerable evidence now supports the concept that development of CRPC is causally related to continued transactivation of AR. The androgen receptor is involved in the transcriptional regulation of endogenous androgen-regulated prostate-specific marker genes such as PSA and TMPRSS2 which are used to monitor treatment responses, prognosis, and progression as their concentrations correlate with tumor size in prostatic cancer [36, 37]. BIC is a non-steroidal anti-androgen used in the treatment of locally advanced and metastatic prostate cancer. Owing to its tolerable side effect profile, ease of administration, and long half-life, it offers an attractive alternative strategy compared to the steroidal anti-androgens [38]. However, the mechanism by which BIC induces apoptosis remains unclear. Defining exact pathways or precise cellular mechanism by which BIC induces its apoptotic effects would enhance our understanding of its role in prostate cancer. Promoting apoptosis in advanced disease with 
(a)
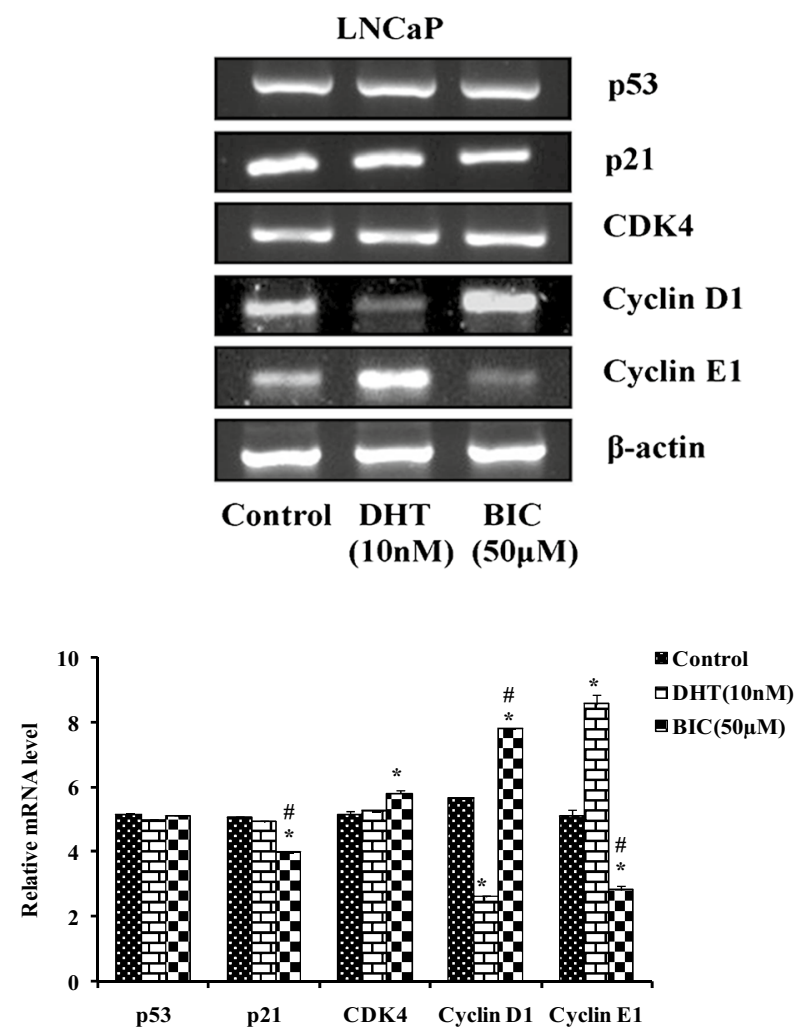

Fig. 7 Effects of DHT and BIC on the expression of mRNAs of cell cycle regulators in (a) $\mathrm{LNCaP}$ cells and (b) PC-3 cells. LNCaP or PC-3 cells $\left(5 \times 10^{5}\right.$ cells/well $)$ were treated with or without DHT (10 $\mathrm{nM})$ or BIC $(50$ and $75 \mu \mathrm{M})$ for $48 \mathrm{~h}$ in a 6 -well plate. Total RNA was isolated from cells and cDNA was prepared by RT and subjected PCR using specific primers of cell cycle regulators. Expression of $\beta$-actin was used as a positive control and for normalization. Data

BIC would represent a major therapeutic breakthrough for prostate cancer research.

In the present study, we have chosen two cell lines representing the hormonal therapeutic spectrum of prostate cell physiology: first the LNCaP cells, which are benign, androgen sensitive, and receptor positive, and second the PC-3 cells, which are derived from malignant prostate tissue and are androgen-independent. Comparing the effect of DHT or BIC on these two cell lines mirrors the clinical dilemma of hormonal treatment. In our initial experiments, the effect of DHT and BIC was evaluated on cell viability of LNCaP and PC-3 cells. Consistent with the findings of Horoszewicz et al. [39], DHT induced cell proliferation of LNCaP cells and showed no effect on PC-3 cells, suggesting that LNCaP cells are androgenresponsive and $\mathrm{PC}-3$ are androgen-non-responsive cells (Fig. 1a, b). However, BIC decreases the cell viability of both LNCaP and PC-3 cells. However, the androgenindependent PC-3 cells showed a less marked apoptotic (b)
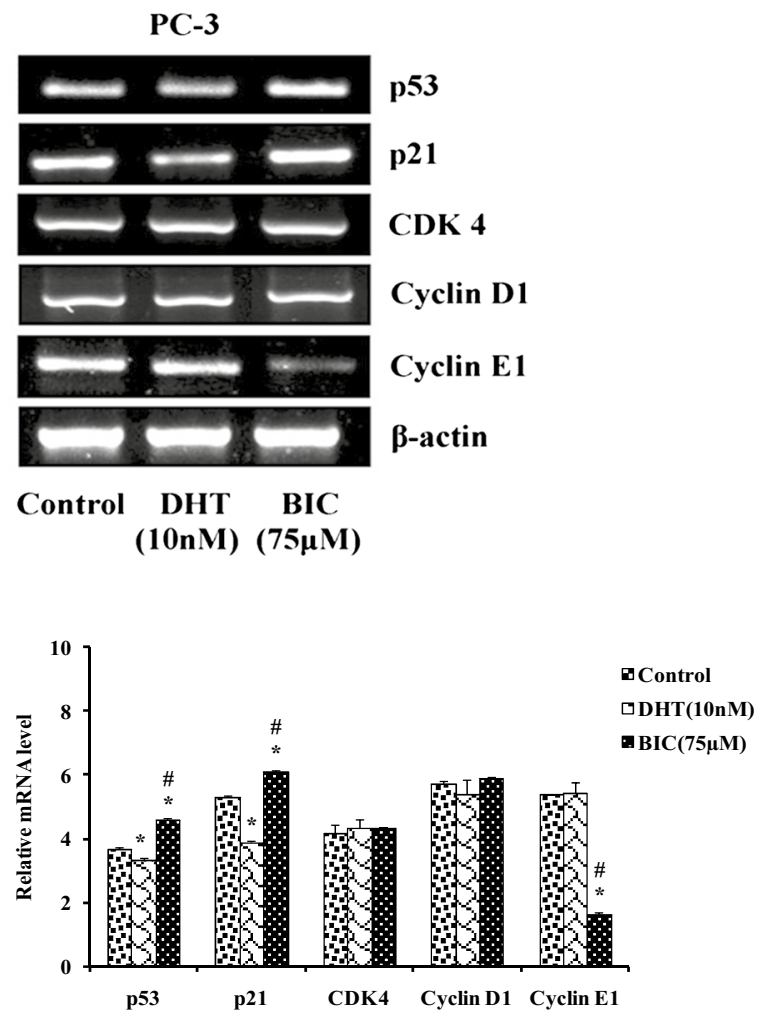

shown are mean \pm SD from three independent experiments. Difference in cell cycle regulators mRNA levels are statistically significant: if $* P<0.05$ compared to control cells, ${ }^{\#} P<0.05$ compared with DHTtreated condition values using one-way ANOVA followed by post hoc Tukey test. The bar graph represents the densitometric analysis of mRNA levels of cell cycle regulators

response to BIC as compared to the androgen-dependent LNCaP cell line (Fig. 2a, b). This represented an interesting finding that a drug (BIC) that ostensibly acts as a receptor antagonist induced cell death in a receptor-negative cell line. Our results are in good agreement with earlier studies reported by Jing $\mathrm{Li}$ et al. [40], wherein a high dose of BIC inhibited growth curves in androgen receptor-negative PC-3 cells, although the method of cell death was thought to be cytotoxic and also receptor-independent [41].

Our studies further investigated the occurrence of $\mathrm{AR}$ expression in LNCaP and PC-3 cells. LNCaP significantly expressed AR and DHT upregulated AR transcripts, whereas BIC suppressed AR transcripts confirming them as androgen-responsive cells. Our results are in good agreement with the findings of Lee et al. [42] who also reported that DHT induced the AR transcriptional level in LNCaP cells. However, in PC-3 cells, there was only a mere or null expression of AR transcripts which confirms them 
(a)
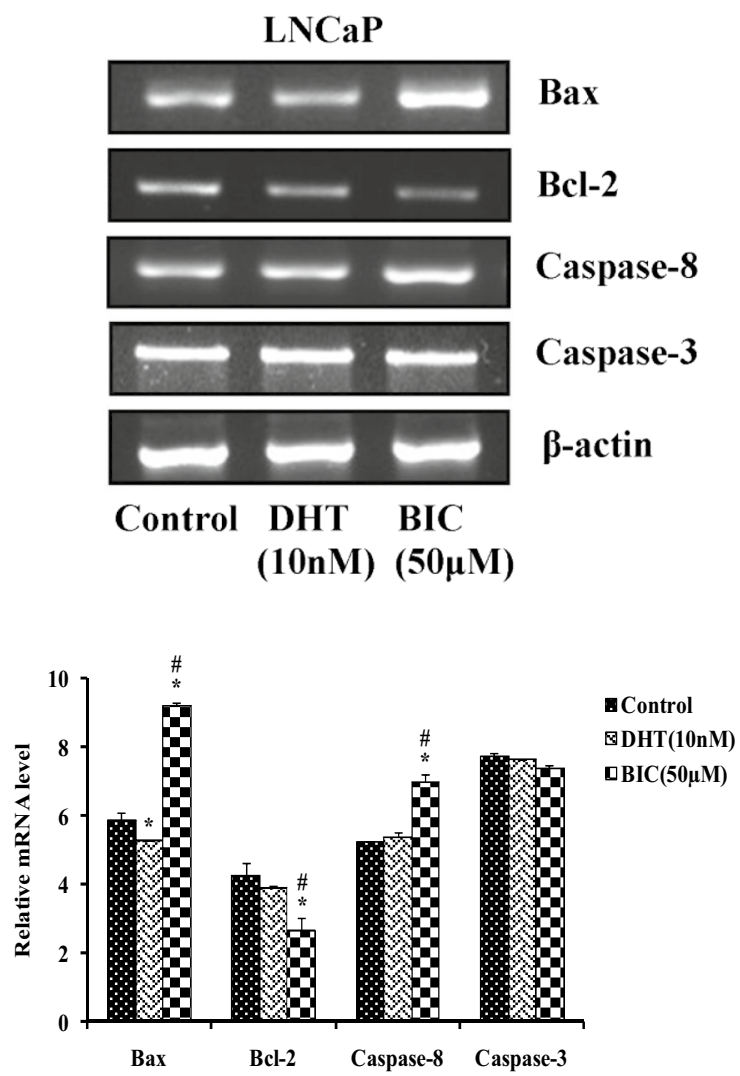

Fig. 8 Effect of DHT and BIC on mRNA levels of Apoptotic genes in (a) LNCaP cells and (b) PC-3 cells. LNCaP or PC-3 cells $\left(5 \times 10^{5}\right.$ cells/well) were treated with or without DHT $(10 \mathrm{nM})$ or BIC (50 and $75 \mu \mathrm{M}$ ) for $48 \mathrm{~h}$ in a 6-well plate. Total RNA was isolated from cells and cDNA was prepared by RT and subjected to 30 cycles of PCR using specific primers of Apoptotic genes. Expression of $\beta$-actin was used as a positive control and for normalization. Data shown

as androgen-non-responsive cells .In particular, we have observed that DHT induced the expression of AR-regulated prostate-specific antigen (PSA) and transmembrane protease serine 2 (TMPRSS2) genes in LNCaP cells, and only marginal increase was observed with PC-3 cells. The increased levels of TMPRSS2 were seen only in moderately differentiated $\mathrm{PCa}$ cells. However, $\mathrm{LNCaP}$ cells are poorly differentiated and hence do not show significant levels of TMPRSS2 mRNA which correlates with the findings of Rajput et al. [43]. These prostate-specific marker genes are known to be upregulated in a majority of prostate cancer patients [44]. In contrast, BIC significantly inhibited the expression of PSA and TMPRSS2 genes in LNCaP cells and this observation was in agreement with the earlier studies [45]. However, DHT or BIC treatments show less or marginal effect on the expression of the above genes in PC-3 cells and this may be due to the difference in AR status. (b)
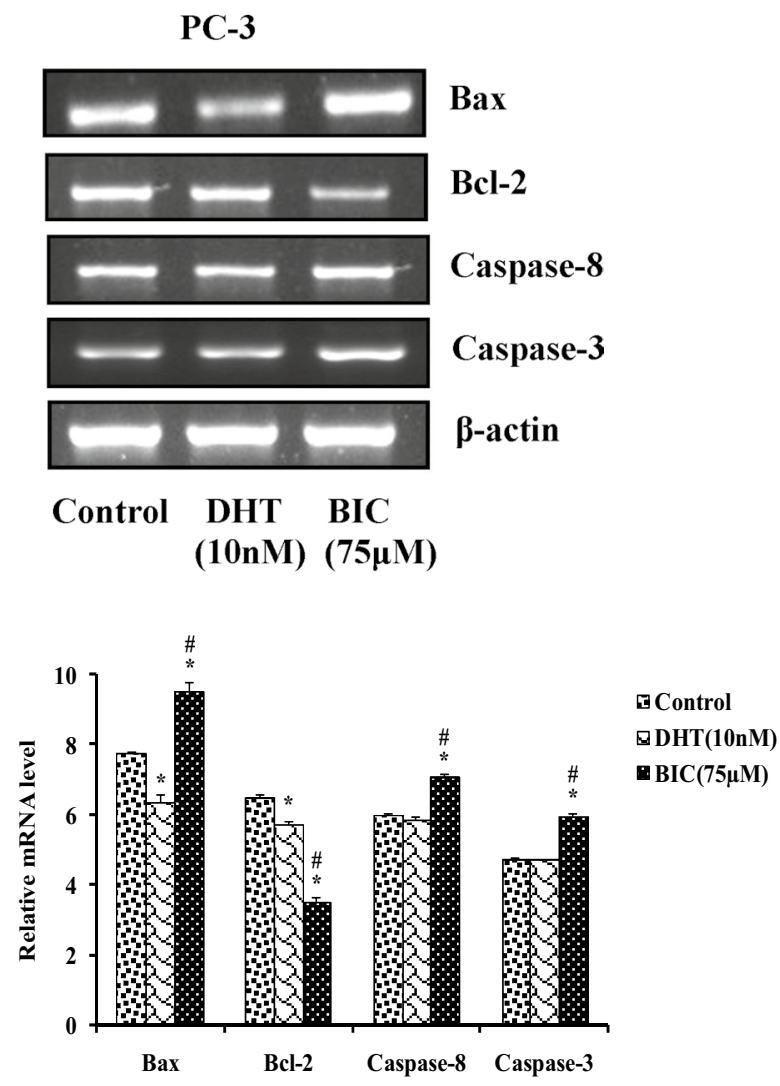

are mean \pm SD from three independent experiments. Differences in Apoptotic gene mRNA levels are statistically significant: if $* P<0.05$ compared to control cells, ${ }^{\#} P<0.05$ compared with DHT-treated condition values using one-way ANOVA followed by post hoc Tukey test. The bar graph represents the densitometric analysis of mRNA levels of Apoptotic genes

AP-1 Protein expression of the oncogene Jun/Fes is widely associated with many types of cancers [19]. The cellular response mediated by AP-1 depends on the complex interplay between the different dimers of the Jun and Fos family members [25, 46]. Expression of Fos and Jun may have a unique role in prostate tumorigenesis and relevance to androgen receptor signaling. Specific AP-1 family members have been shown to have an integral role in androgen-regulated prostate homeostasis, which may provide a mechanism by which they promote prostate tumorigenesis and transformation into CRPC [47]. In the present study, we reported the expression pattern of all the AP-1 factors (c-Jun, Jun-B, Jun-D and c-Fos, Fra-1, Fra-2, and Fos-B) in DHT- and BIC-treated PCa cells. Our studies revealed that DHT significantly induced c-Jun and Fra-1 as key components of the AP-1 complex that underwent changes in LNCaP cells, whereas in PC-3 cells, it was found to be c-Jun and c-Fos. Our results correlate with 
the findings of Ouyang et al. [23] who reported that both c-Jun and c-Fos are upregulated in metastatic prostate cancer, and only high c-Jun expression is associated with poor prognosis. Our results are supported by the earlier findings that suppression of c-Jun using antisense RNA strongly compromised the androgen-dependent proliferation of LNCaP cells [36]. Similarly, patients with high expression levels of the active form of phosphorylated c-Jun had significantly shorter relapse-free survival times, compared with patients with low phosphorylated c-Jun protein expression, suggesting that increased active-cJun levels may promote castration-resistant tumor growth [48]. Previous reports also demonstrate that constitutive activation of c-Jun, Fra-1, and Jun-D is associated with prostate cancer progression towards an androgen-independent phenotype [49]. Treatment of BIC blocked the expression of mRNAs of C-Jun and Fra-1, and in turn also activated the expression of Jun-D in androgen-dependent LNCaP cells. However, in androgen-independent PC-3 cells, BIC inhibited the expression of mRNAs of c-Jun and c-Fos with no effect on Jun-D and Fra-1 transcript. Previous investigation has shown that Fra-1 and Fra-2 and their target genes might be involved in cell invasion and migration [50]. However, Fra-1 was found to be increased in breast cancer where it functions as an oncogene to enhance tumor cell migration [51]. Similar effect of Fra-1 was observed with respect to LNCaP cells, and higher expression of both Fra-1 and Fra-2 was observed in PC-3 cells, compared to LNCaP, and Fra-1 may have multiple roles depending on the tumor type and conditions. In PC-3 cells, constitutive expression and non-responsiveness of Fra-1 transcript at both mRNA and protein level may probably lead to aggressive behavior of PC-3 cells that needs to be investigated and confirmed using in vivo model system. Many groups reported that Jun-D and Fra-2 are relevant in maintaining functional, differentiated cells. For example, Jun-D and Fra- 2 have been associated with growth inhibition/differentiation induced by various stimuli in a wide variety of cell types, such as mouse fibroblasts [52] muscle cells [53], and osteoblasts [54]; and human chronic myelogenous leukemia cells [55], intestinal epithelial cells [56], and ovarian cancer cells [57]. Overall, the results suggested that the differential expression of AP-1 factors may have role in the transformation of more aggressive AR-negative PC-3 cells into CRPC that needs further investigation in in vivo models.

AP-1 factors control various cellular processes through their ability to regulate the expression and function of cell cycle regulators and apoptotic genes [16]. Our studies show that DHT induced the expression of cyclin E1 mRNA transcript, while BIC inhibited the expression of cyclin E1 in LNCaP cells. As studies have shown that cyclin E1 activity was required for cell cycle progression [58] and cyclin D1 was shown to act as an AR co-repressor [59], we considered the possibility that cyclin D1 may mediate the inhibitory effect in response to BIC treatment, while the nonresponsiveness of AR-negative PC- 3 cell towards DHT on cell cycle regulation confirms that the cells probably lost the control over AR-regulated genes. However, BIC significantly decreased the cyclin E1 mRNA levels suggesting that probably it is acting through non-genomic action via Ras/Raf/MAP kinase, PI3K, and PKC cascades that may influence cell cycle regulation and/or increase cell proliferation through AP-1 transcription factors [60]. Both Bcl-2 and Bax gene families acts as a key factor, and their ratio plays an important role in regulation of endogenous mitochondrial apoptosis pathway [61]. Our results depict that the BIC increased the pro-apoptotic Bax and decreased anti-apoptotic $\mathrm{Bcl} 2$ expression in both $\mathrm{LNCaP}$ and $\mathrm{PC}-3$ cells. Activation of both caspase- 8 and 3 mRNAs following the treatment with BIC in PC-3 and caspase- 8 mRNA activation in LNCaP cells suggested that BIC induced the apoptosis via both extrinsic and intrinsic pathways.

In conclusion, our study demonstrated that there is a difference in expression of individual AP-1 transcription factors in androgen-dependent $\mathrm{LNCaP}$ and androgen-independent PC-3 cells as these factors are stage-specific.DHT induced AR-activated AP-1 activity in AR-positive LNCaP cells, while in AR-negative PC-3 cells, it was AR-independent activation of AP-1 activity. Further, BIC significantly decreased Fra-1 transcript in LNCaP cells and found to have no effect in PC-3 cells suggesting that Fra-1 may play a key role in the development of androgen-independent PC-3 cells. Overall, findings from the present study support that Fra-1 could be an exciting target for prevention of transition to CRPC status with effective medication, and prostate cancer treatment.

Acknowledgements The authors wish to express their gratitude to the Department of Science and Technology-Promotion of University Research and Scientific Excellence (DST-PURSE) [SR/59/Z23/2010/38(c)] and University Grant Commission-Centre with Potential for Excellence in Particular Area (UGC-CPEPA) [8-2/2008(NS/ PE)], New Delhi for providing financial support. The authors also wish to express their gratitude to the Department of Microbiology and Biotechnology, Bangalore University, Bengaluru for providing the DST-FIST, UGC-SAP, and department facility.

\section{Compliance with ethical standards}

Conflict of interest The authors declare that they have no conflict of interest.

\section{References}

1. American Cancer Society (ACS) (2010) Cancer facts and figures. American Cancer Society, Atlanta 
2. Heinlein CA, Chang C (2004) Androgen receptor in prostate cancer. Endocr Rev 25:276-308. doi:10.1210/er.2002-0032

3. Lonergan PE, Tindall DJ (2011) Androgen receptor signaling in prostate cancer development and progression. J Carcinog 10:20. doi:10.4103/1477-3163.83937

4. Taplin ME, Ho SM (2001) Clinical review 134: The endocrinology of prostate cancer. J Clin Endocrinol Metab 86:3467-3477. doi:10.1210/jcem.86.8.7782

5. Dehm SM, Tindall DJ (2007) Androgen receptor structural and functional elements: role and regulation in prostate cancer. Mol Endocrinol 21:2855-2863. doi:10.1210/me.2007-0223

6. Attar RM, Takimoto CH, Gottardis MM (2009) Castration-resistant prostate cancer: locking up the molecular escape routes. Clin Cancer Res 15:3251-3255. doi:10.1158/1078-0432.ccr-08-1171

7. Bennett NC, Gardiner RA, Hooper JD, Johnson DW, Gobe GC (2010) Molecular cell biology of androgen receptor signalling. Int J Biochem Cell Biol 42:813-827. doi:10.1016/j. biocel.2009.11.013

8. Miyamoto H, Messing EM, Chang C (2004) Androgen deprivation therapy for prostate cancer: current status and future prospects. Prostate 61:332-353. doi:10.1002/pros.20115

9. Masiello D, Cheng S, Bubley GJ, Lu ML, Balk SP (2002) Bicalutamide functions as an androgen receptor antagonist by assembly of a transcriptionally inactive receptor. J Biol Chem 277:26321-26326. doi:10.1074/jbc.M203310200

10. Floyd MS Jr, Teahan SJ, Fitzpatrick JM, Watson RW (2009) Differential mechanisms of bicalutamide-induced apoptosis in prostate cell lines. Prostate Cancer Prostatic Dis 12:25-33. doi:10.1038/pcan.2008.23

11. Feldman BJ, Feldman D (2001) The development of androgen-independent prostate cancer. Nat Rev Cancer 1:34-45. doi:10.1038/35094009

12. Debes JD, Tindall DJ (2002) The role of androgens and the androgen receptor in prostate cancer. Cancer Lett 187:1-7

13. Shaulian E, Karin M (2002) AP-1 as a regulator of cell life and death. Nat Cell Biol 4:E131-E136. doi:10.1038/ncb0502-e131

14. Eferl R, Wagner EF (2003) AP-1: a double-edged sword in tumorigenesis. Nat Rev Cancer 3:859-868. doi:10.1038/nrc1209

15. Angel P, Karin M (1991) The role of Jun, Fos and the AP-1 complex in cell-proliferation and transformation. Biochim Biophys Acta 1072:129-157

16. Shaulian E, Karin M (2001) AP-1 in cell proliferation and survival. Oncogene 20:2390-2400. doi:10.1038/sj.onc.1204383

17. Hess J, Angel P, Schorpp-Kistner M (2004) AP-1 subunits: quarrel and harmony among siblings. J Cell Sci 117:5965-5973. doi:10.1242/jcs.01589

18. Kaminska B, Pyrzynska B, Ciechomska I, Wisniewska M (2000) Modulation of the composition of AP-1 complex and its impact on transcriptional activity. Acta Neurobiol Exp (Wars) 60:395-402

19. Wisdom R (1999) AP-1: one switch for many signals. Exp Cell Res 253:180-185. doi:10.1006/excr.1999.4685

20. Ripple MO, Henry WF, Rago RP, Wilding G (1997) Prooxidantantioxidant shift induced by androgen treatment of human prostate carcinoma cells. J Natl Cancer Inst 89:40-48

21. Allen RG, Tresini M (2000) Oxidative stress and gene regulation. Free Radic Biol Med 28:463-499

22. Bubulya A, Wise SC, Shen XQ, Burmeister LA, Shemshedini L (1996) c-Jun can mediate androgen receptor-induced transactivation. J Biol Chem 271:24583-24589

23. Ouyang X, Jessen WJ, Al-Ahmadie H, Serio AM, Lin Y, Shih WJ, Reuter VE, Scardino PT, Shen MM, Aronow BJ, Vickers AJ, Gerald WL, Abate-Shen C (2008) Activator protein-1 transcription factors are associated with progression and recurrence of prostate cancer. Cancer Res 68:2132-2144. doi:10.1158/00085472.CAN-07-6055
24. Babu RL, Naveen Kumar M, Patil RH, Devaraju KS, Ramesh GT, Sharma SC (2013) Effect of estrogen and tamoxifen on the expression pattern of AP-1 factors in MCF-7 cells: role of c-Jun, c-Fos, and Fra-1 in cell cycle regulation. Mol Cell Biochem 380:143-151. doi:10.1007/s11010-013-1667-x

25. Patil RH, Babu RL, Naveen Kumar M, Kiran Kumar KM, Hegde SM, Nagesh R, Ramesh GT, Sharma SC (2016) Anti-inflammatory effect of apigenin on LPS-induced pro-inflammatory mediators and AP-1 factors in human lung epithelial cells. Inflammation 39:138-147. doi:10.1007/s10753-015-0232-z

26. Sharma SC, Clemens JW, Pisarska MD, Richards JS (1999) Expression and function of estrogen receptor subtypes in granulosa cells: regulation by estradiol and forskolin. Endocrinology 140:4320-4334. doi:10.1210/endo.140.9.6965

27. Patil RH, Babu RL, Naveen Kumar M, Kiran Kumar KM, Hegde SM, Ramesh GT, Chidananda Sharma S (2015) Apigenin inhibits PMA-induced expression of pro-inflammatory cytokines and AP-1 factors in A549 cells. Mol Cell Biochem 403:95-106. doi:10.1007/s11010-015-2340-3

28. Hegde SM, Kumar MN, Kavya K, Kumar KM, Nagesh R, Patil RH, Babu RL, Ramesh GT, Sharma SC (2016) Interplay of nuclear receptors (ER, PR, and GR) and their steroid hormones in MCF-7 cells. Mol Cell Biochem 422:109-120. doi:10.1007/ s11010-016-2810-2

29. Arnold JT, Isaacs JT (2002) Mechanisms involved in the progression of androgen-independent prostate cancers: it is not only the cancer cell's fault. Endocr Relat Cancer 9:61-73

30. Cunha GR, Donjacour AA, Cooke PS, Mee S, Bigsby RM, Higgins SJ, Sugimura Y (1987) The endocrinology and developmental biology of the prostate. Endocr Rev 8:338-362. doi:10.1210/ edrv-8-3-338

31. Church DR, Lee E, Thompson TA, Basu HS, Ripple MO, Ariazi EA, Wilding G (2005) Induction of AP-1 activity by androgen activation of the androgen receptor in $\mathrm{LNCaP}$ human prostate carcinoma cells. Prostate 63:155-168. doi:10.1002/pros.20172

32. Shiota M, Yokomizo A, Naito S (2011) Increased androgen receptor transcription: a cause of castration-resistant prostate cancer and a possible therapeutic target. J Mol Endocrinol 47:R25-R41. doi:10.1530/jme-11-0018

33. Nakamura K, Yasunaga Y, Segawa T, Ko D, Moul JW, Srivastava S, Rhim JS (2002) Curcumin down-regulates AR gene expression and activation in prostate cancer cell lines. Int $\mathrm{J}$ Oncol 21:825-830

34. Lorenzo PI, Saatcioglu F (2008) Inhibition of apoptosis in prostate cancer cells by androgens is mediated through downregulation of c-Jun N-terminal kinase activation. Neoplasia 10:418-428

35. Sato N, Sadar MD, Bruchovsky N, Saatcioglu F, Rennie PS, Sato S, Lange PH, Gleave ME (1997) Androgenic induction of prostate-specific antigen gene is repressed by protein-protein interaction between the androgen receptor and AP-1/c-Jun in the human prostate cancer cell line LNCaP. J Biol Chem 272:17485-17494

36. Chen SY, Cai C, Fisher CJ, Zheng Z, Omwancha J, Hsieh CL, Shemshedini L (2006) c-Jun enhancement of androgen receptor transactivation is associated with prostate cancer cell proliferation. Oncogene 25:7212-7223. doi:10.1038/sj.onc.1209705

37. Tan MH, Li J, Xu HE, Melcher K, Yong EL (2015) Androgen receptor: structure, role in prostate cancer and drug discovery. Acta Pharmacol Sin 36:3-23. doi:10.1038/aps.2014.18

38. Wirth MP, Hakenberg OW and Froehner M (2007) Antiandrogens in the treatment of prostate cancer. Eur Urol 51:306-313. doi:10.1016/j.eururo.2006.08.043 (discussion 314)

39. Horoszewicz JS, Leong SS, Kawinski E, Karr JP, Rosenthal H, Chu TM, Mirand EA, Murphy GP (1983) LNCaP model of human prostatic carcinoma. Cancer Res 43:1809-1818 
40. Li J, Xiang S, Zhang Q, Wu J, Tang Q, Zhou J, Yang L, Chen Z, Hann SS (2015) Combination of curcumin and bicalutamide enhanced the growth inhibition of androgen-independent prostate cancer cells through SAPK/JNK and MEK/ERK1/2-mediated targeting NF-kappaB/p65 and MUC1-C. J Exp Clin Cancer Res 34:46. doi:10.1186/s13046-015-0168-Z

41. Vicentini C, Festuccia C, Angelucci A, Gravina GL, Muzi P, Eleuterio E, Miano R, Marronaro A, Tubaro A, Bologna M (2002) Bicalutamide dose-dependently inhibits proliferation in human prostatic carcinoma cell lines and primary cultures. Anticancer Res 22:2917-2922

42. Lee EC, Zhan P, Schallhom R, Packman K, Tenniswood M (2003) Antiandrogen-induced cell death in LNCaP human prostate cancer cells. Cell Death Differ 10:761-771. doi:10.1038/ sj.cdd. 4401228

43. Rajput AB, Miller MA, De Luca A, Boyd N, Leung S, Hurtado-Coll A, Fazli L, Jones EC, Palmer JB, Gleave ME, Cox ME, Huntsman DG (2007) Frequency of the TMPRSS2:ERG gene fusion is increased in moderate to poorly differentiated prostate cancers. J Clin Pathol 60:1238-1243. doi:10.1136/ jcp.2006.043810

44. Vaarala MH, Porvari K, Kyllonen A, Lukkarinen O, Vihko P (2001) The TMPRSS2 gene encoding transmembrane serine protease is overexpressed in a majority of prostate cancer patients: detection of mutated TMPRSS 2 form in a case of aggressive disease. Int J Cancer 94:705-710

45. Andersen RJ, Mawji NR, Wang J, Wang G, Haile S, Myung JK, Watt K, Tam T, Yang YC, Banuelos CA, Williams DE, McEwan IJ, Wang Y, Sadar MD (2010) Regression of castrate-recurrent prostate cancer by a small-molecule inhibitor of the amino-terminus domain of the androgen receptor. Cancer Cell 17:535546. doi:10.1016/j.ccr.2010.04.027

46. Chinenov Y, Kerppola TK (2001) Close encounters of many kinds: Fos-Jun interactions that mediate transcription regulatory specificity. Oncogene 20:2438-2452. doi:10.1038/ sj.onc. 1204385

47. Feng Z, Joos HJ, Vallan C, Muhlbauer R, Altermatt HJ, Jaggi $\mathrm{R}$ (1998) Apoptosis during castration-induced regression of the prostate is Fos dependent. Oncogene 17:2593-2600. doi:10.1038/sj.onc.1202195

48. Edwards J, Krishna NS, Mukherjee R, Bartlett JM (2004) The role of c-Jun and c-Fos expression in androgen-independent prostate cancer. J Pathol 204:153-158. doi:10.1002/path0.1605

49. Zerbini LF, Wang Y, Cho JY, Libermann TA (2003) Constitutive activation of nuclear factor kappaB p50/p65 and Fra-1 and JunD is essential for deregulated interleukin 6 expression in prostate cancer. Cancer Res 63:2206-2215

50. Vaz M, Machireddy N, Irving A, Potteti HR, Chevalier K, Kalvakolanu D, Reddy SP (2012) Oxidant-induced cell death and
Nrf2-dependent antioxidative response are controlled by Fra-1/ AP-1. Mol Cell Biol 32:1694-1709. doi:10.1128/MCB.06390-11

51. Yang S, Li Y, Gao J, Zhang T, Li S, Luo A, Chen H, Ding F, Wang X, Liu Z (2013) MicroRNA-34 suppresses breast cancer invasion and metastasis by directly targeting Fra-1. Oncogene 32:4294-4303. doi:10.1038/onc.2012.432

52. Pfarr CM, Mechta F, Spyrou G, Lallemand D, Carillo S, Yaniv M (1994) Mouse JunD negatively regulates fibroblast growth and antagonizes transformation by ras. Cell 76:747-760

53. Andreucci JJ, Grant D, Cox DM, Tome LK, Prywes R, Goldhamer DJ, Rodrigues N, Bedard PA, McDermott JC (2002) Composition and function of AP-1 transcription complexes during muscle cell differentiation. J Biol Chem 277:16426-16432. doi:10.1074/jbc.M110891200

54. McCabe LR, Banerjee C, Kundu R, Harrison RJ, Dobner PR, Stein JL, Lian JB, Stein GS (1996) Developmental expression and activities of specific fos and jun proteins are functionally related to osteoblast maturation: role of Fra-2 and Jun D during differentiation. Endocrinology 137:4398-4408. doi:10.1210/ endo.137.10.8828501

55. Lasky SR, Iwata K, Rosmarin AG, Caprio DG, Maizel AL (1995) Differential regulation of JunD by dihydroxycholecalciferol in human chronic myelogenous leukemia cells. J Biol Chem 270:19676-19679

56. Li L, Liu L, Rao JN, Esmaili A, Strauch ED, Bass BL, Wang JY (2002) JunD stabilization results in inhibition of normal intestinal epithelial cell growth through P21 after polyamine depletion. Gastroenterology 123:764-779

57. Gunthert AR, Grundker C, Hollmann K, Emons G (2002) Luteinizing hormone-releasing hormone induces JunD-DNA binding and extends cell cycle in human ovarian cancer cells. Biochem Biophys Res Commun 294:11-15. doi:10.1016/ S0006-291X(02)00427-8

58. Balk SP, Knudsen KE (2008) AR, the cell cycle, and prostate cancer. Nucl Recept Signal 6:e001. doi:10.1621/nrs.06001

59. Comstock CE, Augello MA, Schiewer MJ, Karch J, Burd CJ, Ertel A, Knudsen ES, Jessen WJ, Aronow BJ, Knudsen KE (2011) Cyclin D1 is a selective modifier of androgen-dependent signaling and androgen receptor function. J Biol Chem 286:8117-8127. doi:10.1074/jbc.M110.170720

60. Edwards J, Bartlett JM (2005) The androgen receptor and signaltransduction pathways in hormone-refractory prostate cancer. Part 2: Androgen-receptor cofactors and bypass pathways. BJU Int 95:1327-1335. doi:10.1111/j.1464-410X.2005.05527.x

61. Burlacu A (2003) Regulation of apoptosis by Bcl-2 family proteins. J Cell Mol Med 7:249-257 